Author Accepted Manuscript, 28.03.2017: Manning, C. \& Hobson, A.J., Judgemental and developmental mentoring in Further Education Initial Teacher Education in England: Mentor and mentee perspectives, Research in Post-compulsory Education.

\title{
Judgemental and developmental mentoring in Further Education Initial Teacher Education in England: Mentor and mentee perspectives
}

\author{
Catherine Manning and Andrew J. Hobson \\ School of Education, University of Brighton, Brighton, England \\ E-mail for the corresponding author: c.manning1@uni.brighton.ac.uk
}

\begin{abstract}
This article presents findings from a study which sought to identify the extent to which trainee teachers and their mentors considered their mentoring experiences and approaches to be judgemental or developmental. The article draws on a case study of trainee teachers and mentors on an Initial Teacher Education programme at a Further Education college on the south coast of England. Data were generated from an initial survey of 22 teachers, from which seven pairs of teachers and mentors also participated in part-structured individual interviews and direct observation of one of their mentoring meetings. In addition, 8 of the interviewees also participated in a follow up email survey. The findings highlight significant variation in mentoring practices, with both judgemental and developmental mentoring approaches in use. A distinct discrepancy is also identified between the perceptions of mentors and mentees regarding the nature of the mentoring experience, with most mentors describing their approaches as developmental and most mentees describing these as judgemental. In addition, mentor education was found to enhance mentors' enactment of developmental as opposed to judgemental mentoring. A number of possible implications for policy, practice and further research are discussed
\end{abstract}

Keywords: further education, initial teacher education, judgementoring, developmental mentoring, mentor education

\section{Introduction}

This article presents findings from a case study of mentoring for trainee teachers in the Further Education and Skills (FE) sector in England. The FE sector is also sometimes referred to as Post-Compulsory Education or the Lifelong Learning sector. It is diverse and includes further education colleges, sixth form colleges, adult and community learning providers, prisons, work-based learning providers, and private training companies. In contrast to schools, where most trainee teachers undertake a full-time, pre-service Initial Teacher Education (ITE) course, in FE the majority of new teachers begin a paid teaching role, and then undertake teacher education courses on a part-time, in-service basis. As such, these individuals adopt a dual role of both teacher and parttime student; hence, we refer to them here on in as 'teacher students'. In this context, we define mentoring as a one to one relationship between a teacher student (the mentee) 
Author Accepted Manuscript, 28.03.2017: Manning, C. \& Hobson, A.J., Judgemental and developmental mentoring in Further Education Initial Teacher Education in England: Mentor and mentee perspectives, Research in Post-compulsory Education.

and a qualified and usually more experienced teacher (the mentor), which aims to support the mentee's learning and development as a teacher.

Recent studies identify an emerging judgemental approach to mentoring in the sector which is contrasted with an earlier more developmental approach (Tedder and Lawy, 2009; Cullimore and Simmons, 2010; Ingleby and Tummons, 2012; Ingleby, 2014). Studies suggest that this change in approach is related to mentors' involvement in the evaluation of teacher students' performance, and that an overemphasis on assessment may be constraining the effectiveness of mentoring by restricting dialogue between mentors and teacher students (Duckworth and Maxwell, 2015, 17), impeding the development of reflective practice (Ingleby, 2014, 27) and diminishing the transformative potential of mentoring (Tedder and Lawy, 2009, 427).

We extend this literature - and the relatively small evidence base on mentoring in FE ITE more generally - by presenting our analyses of a study which examined the extent to which the enactment of mentoring in a specific FE ITE context could be considered to be judgemental or developmental. Most previous studies rely on mentors' and mentees' accounts of the mentoring experience, with some drawing solely on the perspectives of mentors or mentees. Despite its limited scale, the present study is relatively unique in that it employs triangulation involving the analysis of data generated from mentees, their mentors and direct (non-participant) observation of the dyads' mentoring meetings.

Before proceeding to a brief discussion of the policy and research context, we explain our use of the terms developmental and judgemental mentoring, and clarify our own position on alternative approaches to mentoring teacher students.

\section{Theoretical framework}

Our conception of developmental mentoring draws largely on Clutterbuck (2004). Mentoring is a 'holistic' role which potentially incorporates those of counsellor, guide, networker and coach (Clutterbuck, 2004; Klasen and Clutterbuck, 2002) to enable mentors to provide 'a spectrum of learning and support behaviours' (Clutterbuck, 2004, $3)$. In general, mentors may adopt relatively directive or non-directive approaches to mentoring. The former approach is characterised by the mentor taking 'primary responsibility for managing the relationship', which may include: 'deciding the content, timing, and direction of discussion; ...pointing the mentee to specific career or personal goals, or ... giving strong advice and suggestions' (Clutterbuck, 2004, 15). In contrast, non-directive mentoring 'encourages the mentee to set the agenda and initiate meetings, encourages the mentee to come to his or her own conclusions about the way forward and generally stimulates the development of self-reliance' (Clutterbuck, 2004, 15). We concur with Clutterbuck's position that a non-directive approach to mentoring will tend to be more 'developmental and empowering' (Clutterbuck, 2004, 13). Developmental mentoring relies on trust and openness in the relationship, which can be difficult to achieve where one person has authority over another (Clutterbuck, 2004, 13). It thus tends to work best as an 'off-line' relationship between colleagues or peers rather than a hierarchical arrangement (Clutterbuck, 2004, 13).

In the context of ITE, we consider, in accordance with the principles of developmental mentoring, that one of the key objectives of mentoring is to seek to 
Author Accepted Manuscript, 28.03.2017: Manning, C. \& Hobson, A.J., Judgemental and developmental mentoring in Further Education Initial Teacher Education in England: Mentor and mentee perspectives, Research in Post-compulsory Education.

enhance mentees' continuing professional development (CPD) or lifelong learning by facilitating their development of 'learnacy' (Claxton, 2004) - explained in this context as mentees' ability to manage their on-going learning from their own and others' experiences of teaching (Hobson and Malderez, 2013; Malderez, 2015). In keeping with this developmental conception of mentoring, Feiman-Nemser (2001) and Norman and Feiman-Nemser (2005) provide specific examples of techniques or 'moves' an 'educative' mentor may adopt in order to become 'a co-thinker' with new teachers, such as 'pinpointing problems', 'noticing signs of growth' and 'modelling wondering about teaching'.

Our conception of judgemental mentoring is partly informed by the notion of directive mentoring but also draws on the concept of 'judgementoring', which Hobson and Malderez (2013) found to be prevalent in the schools sector in England, and which they defined as a relationship in which the mentor,

in revealing too readily and/or too often her/his own judgements on or evaluations of the mentee's planning and teaching (e.g. through "comments", "feedback", advice, praise, or criticism), compromises the mentoring relationship and its potential benefits. (Hobson and Malderez, 2013, 90)

Here the process of mentoring centres around the mentor making evaluative comments on the mentee's 'performance', with relatively little emphasis on developing mentees' own critical analysis of their practice, and little concern for their well-being. It is important to note that it is not mentors' evaluations per se, but rather the precedence and proliferation of the mentor's evaluations - or of the mentor 'passing judgement' in mentoring conversations that are considered to result in the restrictive form of mentoring that is 'judgementoring'. As previous research has suggested (e.g. Bullough, 2005; Young et al., 2005), teacher students may sometimes benefit from (relatively directive) constructive feedback from mentors, particularly perhaps at the start of their ITE programme. However, the over-use of directive and evaluative approaches ('judgementoring') is likely to constrain a mentee's learning and development: firstly by impeding mentees' openness about, or encouraging them to fabricate, their professional learning and development needs for fear that their mentor will judge them (Hobson and McIntyre, 2013); secondly by promoting the kind of 'learned helplessness' (Maier and Seligman, 1976) that can result from an over-reliance on others, which is antithetical to the development of learnacy.

\section{Policy and Research Context}

Until the late 1990s in England, there were few regulations relating to teaching standards in FE (Lucas, 2013). In 1997, the newly elected Labour Government identified $\mathrm{FE}$ as central to widening participation in education and improving the country's economic effectiveness (Orr and Simmons, 2010). They announced concerns around teaching standards in the sector and subsequent policy reforms in 2001 and 2007 led to a legislative requirement for all FE teachers to hold teaching qualifications. In addition, from 2003 onwards the Office for Standards in Education (Ofsted) ${ }^{i}$ began inspecting FE ITE provision.

The first Ofsted survey of FE ITE concluded that 'the current system of FE teacher training does not provide a satisfactory foundation of professional development 
Author Accepted Manuscript, 28.03.2017: Manning, C. \& Hobson, A.J., Judgemental and developmental mentoring in Further Education Initial Teacher Education in England: Mentor and mentee perspectives, Research in Post-compulsory Education.

for FE teachers at the start of their careers' (Ofsted, 2003, 2). In this report the lack of systematic and effective mentoring arrangements for teacher students was described as 'a major weakness' (ibid., 18). Subsequent annual inspection reports on FE ITE provision were published and by 2009 improvements were noted as nearly all teacher students were receiving mentoring support (Ofsted, 2009). However, as highlighted by Cullimore and Simmons' (2010), there appears to have been an increasing expectation from Ofsted that mentors would formally evaluate teacher students' performance. In 2008 , for example, mentors were criticised for not making 'accurate judgements about teaching and learning...in particular about the boundaries between pass and fail grades' (Ofsted, 2008, 5). Scholars argue these changes are symptomatic of a performative culture pervading the education sector (Ball, 2003), and have 'imposed a judgemental approach to mentoring' (Duckworth and Maxwell, 2015,8) in which mentors typically act as judge and assessor (Tedder and Lawy, 2009; Cullimore and Simmons, 2010; Ingleby and Tummons, 2012). ${ }^{\text {ii }}$ Furthermore, a number of these studies have found that mentors' involvement in the formal assessment of teacher students has resulted in some mentors experiencing tensions, boundary issues or unease and that mentors (and teacher students themselves) tend to favour a developmental model of mentoring (Ingleby and Tummons, 2012; Cullimore and Simmons, 2010; Tedder and Lawy, 2009; Garbett et al. 2013).

There is, however, a lack of consensus in the international research literature regarding the legitimacy or otherwise of mentors' involvement in formal assessment of their mentees. Several studies (e.g., Bradbury and Koballa, 2008; Tee Ng, 2012) suggest that mentoring tends to be more effective when mentors are not involved in formally assessing, evaluating or appraising the work of their mentees, and that mentors who do not have an assessor role are more able to create a 'safe' space for teacher students 'to negotiate the practices, expectations and performance measures that define their work contexts' (McIntyre and Hobson, 2016, 149). However, some studies (e.g., Foster, 1999; Yusko and Feiman-Nemser, 2008) have challenged aspects of this position and argued that good mentors can effectively balance support, development and formal evaluation roles. Findings from Lawy and Tedder (2011) suggest that some mentors are attempting to balance the developmental and judgemental elements of their role, although there is little research evidence of whether or how they may be successfully doing so in practice.

One of the factors that seems likely to influence the models of mentoring enacted is the prevalence and nature of mentor education and training. In England, research indicates that that mentors do not receive adequate preparation for the role (Cunningham, 2007; Ingleby and Hunt, 2008; Hobson and Malderez, 2013), a conclusion which Ofsted also reached from their inspections of FE ITE provision (Ofsted, 2009). In addition, there is evidence to suggest that where mentor education and training does take place, provision is variable in nature and quality. One particular study from England details how mentors attended a one-off, two hour session, which included watching a video of a teacher student and grading their performance (Ingleby, 2014). This raises the question of whether some mentor preparation may be perpetuating a judgemental model of mentoring. However, relatively little is currently known about the impact of such programmes on mentoring practice (Aspfors and Fransson, 2015; Robinson and Hobson, 2017). One exception is Lejonberg et al.'s (2015) quantitative study, which found that mentor education in Norway acted as an antecedent to 'more desirable mentoring practices' and was likely to 'reduce the 
Author Accepted Manuscript, 28.03.2017: Manning, C. \& Hobson, A.J., Judgemental and developmental mentoring in Further Education Initial Teacher Education in England: Mentor and mentee perspectives, Research in Post-compulsory Education.

likelihood of beliefs which may correspond with the practice of judgementoring' (152). We return to this issue below.

We now explain the methods of data generation and analysis employed for the present study (Research Methods), before presenting and discussing our research findings.

\section{Methods}

This study was underpinned by a mixed methods research framework. Drawing on the work of Teddlie and Tashakkori (2010), Hammersley (1996), Pring (2015), and Bryman $(2008,2012)$, our mixed methods approach rejects the incompatibility thesis that upholds a clear 'quantitative' versus 'qualitative' methods divide. We instead favour a framework which, as Tummons (2014) puts it, transcends 'paradigmatic boundaries' and seeks to 'focus on the research questions to be answered and the credibility of those answers, rather than sustaining a focus on spurious distinctions between, or characteristics of, qualitative and/or quantitative research' (p.174). The use of a case study approach (Stake, 2000), in which a single ITE provider represented the case, facilitated the use of multiple methods of data generation in order to produce a threedimensional account of the phenomena under investigation. There were four sequential stages of field work: an online survey for teacher students, observations of a mentoring meeting between teacher student and mentor, individual part-structured interviews with the teacher students and mentors who had participated in the observations, and a follow up email survey for interviewees (see Table 1). The use of these mixed and multiple methods facilitated triangulation which enabled a direct comparison of different perspectives on mentoring approaches in the institution. The conduct of the case study was aided by the fact that the first author had, only until very recently prior to the conduct of the fieldwork, been employed as a teacher educator for four years by the case study institution. This helped to facilitate access to research participants, as well as providing valuable contextual knowledge. We briefly elaborate on each stage and method of data generation.

In autumn 2014, an online survey was distributed, using SurveyMonkey®, to all 28 teacher students who were starting the second year of a two-year, in-service ITE programme at the case study institution. Second year teacher students were recruited as they could draw upon their experiences of mentoring from their first year and would be continuing to work with the same mentors over the forthcoming year. The teacher students were invited to complete a number of both closed and fixed-response questions (e.g. relating to their gender or the number of years they had been teaching), and openended questions relating to their perceptions and experience of mentoring (e.g. what they considered to be the purpose of mentoring). Teacher students were also asked whether they would be willing for a meeting with their mentor to be observed (subject to being selected and the additional consent of their mentor), and to participate in a follow-up interview. As shown in Table 1 below twenty-two teacher students returned completed questionnaires, a response rate of 79 per cent. The use of the questionnaire enabled us to gather teacher students' views on mentoring from a wider range of respondents than could be reached through observation and interviewing (Basit, 2010, 78). It also provided valuable data the preliminary analysis of which informed the identification of a maximum variation sample (Miles and Huberman, 1994) for the subsequent stages of the research. Of the 22 teacher student survey respondents, 11 
Author Accepted Manuscript, 28.03.2017: Manning, C. \& Hobson, A.J., Judgemental and developmental mentoring in Further Education Initial Teacher Education in England: Mentor and mentee perspectives, Research in Post-compulsory Education.

stated that they would be willing to participate in the observation and interview strands of the research, and we subsequently established that the mentors of nine of these mentees were also willing to participate. From the nine willing mentor dyads, we sought to select participants (mentees and mentors):

a) of both genders;

b) from both types of ITE programme being followed (Postgraduate Certificate of Education and Certificate of Education) $)^{\mathrm{iii}}$;

c) who had been teaching for varying lengths of time;

d) who had different subject and vocational specialisms; and

e) (most importantly) whose survey responses suggested that they had contrasting experiences and perceptions of mentoring, including experiences of judgementoring or developmental mentoring.

Seven pairs of teacher students and mentors were invited to participate in observations and follow up individual interviews, and all confirmed their willingness to do so.

\begin{tabular}{|l|l|l|l|}
\hline Method & $\begin{array}{l}\text { No. of individuals } \\
\text { invited to } \\
\text { participate }\end{array}$ & $\begin{array}{l}\text { No. who agreed to } \\
\text { participate }\end{array}$ & $\begin{array}{l}\text { No. of actual } \\
\text { participants }\end{array}$ \\
\hline $\begin{array}{l}\text { Questionnaire for } \\
\text { teacher students }\end{array}$ & 28 teacher students & 22 teacher students & 22 teacher students \\
\hline $\begin{array}{l}\text { Observations of } \\
\text { mentoring meeting } \\
\text { between teacher } \\
\text { student and mentor }\end{array}$ & $\begin{array}{l}28 \text { teacher students } \\
11 \text { mentors }\end{array}$ & $\begin{array}{l}11 \text { teacher students } \\
9 \text { mentors }\end{array}$ & $\begin{array}{l}7 \text { teacher students } \\
7 \text { mentors }\end{array}$ \\
\hline $\begin{array}{l}\text { Individual part- } \\
\text { structured } \\
\text { interviews }\end{array}$ & $\begin{array}{l}28 \text { teacher students } \\
11 \text { mentors }\end{array}$ & $\begin{array}{l}11 \text { teacher students } \\
9 \text { mentors }\end{array}$ & $\begin{array}{l}7 \text { teacher students } \\
7 \text { mentors }\end{array}$ \\
\hline $\begin{array}{l}\text { Subsequent email } \\
\text { survey }\end{array}$ & $\begin{array}{l}7 \text { teacher students } \\
7 \text { mentors }\end{array}$ & $\begin{array}{l}4 \text { student teachers } \\
4 \text { mentors }\end{array}$ & $\begin{array}{l}3 \text { student teachers } \\
4 \text { mentors }\end{array}$ \\
\hline
\end{tabular}

Table 1: Stages of field work and number of participants

The second method of data generation, non-participant observation of mentoring meetings, took place in the participants' usual work environments, in private settings, at a time chosen by the mentor and teacher student to minimise any disruption or change to their routines (Creswell, 2014, 97). All participants gave consent for audio recordings to be made of the meetings that were observed. During the mentoring meeting, the researcher took field notes. The use of observation enabled us to witness the enactment of mentoring first hand, thus to be less reliant on participants' accounts, and to explore a potential difference between what people say they do and what we perceived them to be doing. Nonetheless, participants' experiences and perceptions were also very important to us. Hence the subsequent interviews with mentors and mentees.

This third method of data collection took place around 5-7 days after each of the observations, to provide participants with time and space for reflection after the mentoring conversation. We adopted a 'part-structured' interview approach (Hobson 
Author Accepted Manuscript, 28.03.2017: Manning, C. \& Hobson, A.J., Judgemental and developmental mentoring in Further Education Initial Teacher Education in England: Mentor and mentee perspectives, Research in Post-compulsory Education.

and Townsend, 2010), underpinned by Tomlinson's (1989) notion of 'hierarchical focusing', which seeks to ensure coverage of the researcher's agenda while minimising the researcher's influence on interviewees' accounts. We thus asked a relatively small number of broad questions (e.g. 'Could you give me an overview of your mentoring experiences so far and what you have made of these?') which enabled the interviewee to talk about what was significant to them, relating to these issues, but used prompts or probes where some specific issues in which we were interested (e.g. 'Did you receive any training or preparation for being a mentor?') had not been addressed relatively spontaneously. Mentors and mentees were also provided with a brief description of both judgemental and developmental mentoring and asked which they considered best captured their approach or their experience of mentoring. The descriptions provided were as follows:
Judgemental mentoring: a mentoring approach which is largely based around mentors giving feedback to trainees after observing their lessons. The mentor may initially invite the mentee to comment on how they felt the lesson had gone before outlining the teacher student's strengths and areas for development with suggestions and advice for improvement, as they (mentors) see it.

\begin{abstract}
Developmental mentoring: A mentoring approach which centres more around mentors asking trainees a series of questions which encourage the trainee to analyse their teaching and come to their own conclusions about their developing practice. The mentor is less directive, spends more time listening to the teacher student's analysis and encouraging the trainee to critically reflect on their practice, and seeks to empower the trainee to take responsibility for their professional learning and development.
\end{abstract}

Our final research method involved sending a follow up email survey to teacher students and mentors. This took place at the end of the summer term in 2015, when the teaching qualification was complete and the mentoring relationship had officially ended. This enabled us to compensate for the potential limitation that the data generation from the previous three methods took place between half and two-thirds of the way through teacher students' ITE programmes, so might not have been representative of participants' experience of mentoring on the course as a whole. More specifically, the final email survey enabled us to explore whether the experience of mentoring was perceived by mentees to have become less directive and more developmental over time, as some (e.g. Collet, 2015; Hobson, 2016) have suggested is desirable.

A thematic analysis was initially undertaken of data from the initial and followup email surveys, interview and observation field notes and recordings (Miles, Huberman and Saldana 2014, 277). Themes were related to the research aims of the study, themselves informed by a review of the existing literature and identified gaps in the evidence base. This created a broad, provisional set of deductive codes by which to categorise segments of data (ibid. 81). This was followed by an inductive coding process, whereby segments of data were analysed and given sub-codes, which generated further emergent themes (Saldana, 2013, 14). Field notes and recordings from the observations were also analysed using an event recording system consisting of a schedule of behaviours where we counted and recorded events or behaviours in a tally mark fashion to identify specific mentoring approaches and how frequently they were being used (Simpson and Tuson, 2003, 29). 
Author Accepted Manuscript, 28.03.2017: Manning, C. \& Hobson, A.J., Judgemental and developmental mentoring in Further Education Initial Teacher Education in England: Mentor and mentee perspectives, Research in Post-compulsory Education.

Each stage of this research process has been conducted in accordance with the ethical guidelines of the British Education Research Association (BERA, 2011). For example, pseudonyms are used throughout the findings to protect participants' anonymity and that of the participating institution / ITE provider. Transcripts of interviews were emailed to all participants for their approval and early drafts of the findings were shared. Although there was a risk that doing so might have resulted in a loss of valuable data, this did not materialise in practice, and it offered participants the opportunity to check the accuracy of our interpretations (Basit, 2010; Creswell, 2014) and confirm their informed consent. None of the participants raised concerns and three participants responded to state they were satisfied with the initial findings.

\section{The Case Study Institution and Participants}

This case study took place at Coastal College, an FE college in a city on the south coast of England. Coastal College offers part-time teaching qualifications which are completed over two years: the PGCE for university graduates and the Cert. Ed. for teachers who do not hold a degree. These qualifications are accredited by a local university. Teacher students are either currently employed in the FE sector or have at least fifty hours of teaching confirmed for the coming year.

There is no central system for recruiting mentors at Coastal College; rather the ITE department encourages teacher students to identify a colleague to be their mentor prior to starting the teaching qualification. Mentors are asked to attend an annual mentoring meeting at the beginning of the academic year, which lasts approximately one hour and provides a brief introduction to the role and the paperwork they are required to complete. Attendance at the meeting is typically low. It is not mandatory for mentors to have undertaken any other formal training or preparation for the role. The college has provided some professional development for mentors, for example, in 200910 some mentors in the college undertook a Level 3 mentoring qualification, which was run internally by a member of the Professional Development team, however, at the time of the research there were no such courses on offer.

Mentors are required to complete four formative assessments per year: two lesson observations with follow-up meetings and two mentor reviews, involving a written report from mentors evaluating teacher students' progress in the areas of professional values, subject specialist learning and teaching, and planning. The accrediting university stipulates that mentors do not grade teacher students' performance when undertaking lesson observations. Mentors are paid for six hours of contact with teacher students; the time it takes to complete the formal assessments. The teacher students in this case study worked either at Coastal College or other local FE providers. Each teacher student had a mentor who worked in their institution and either taught the same subject, a similar subject, or a similar group of learners. Table 2 provides details of teacher students who participated in observations and interviews, and shows that teacher students are from diverse subject areas and have varied amounts of previous teaching experience. Details of the mentors who took part in the observations and individual interviews are provided in Table 3. 
Author Accepted Manuscript, 28.03.2017: Manning, C. \& Hobson, A.J., Judgemental and developmental mentoring in Further Education Initial Teacher Education in England: Mentor and mentee perspectives, Research in Post-compulsory Education.

\begin{tabular}{|l|l|l|l|l|l|}
\hline $\begin{array}{l}\text { Teacher } \\
\text { student }\end{array}$ & Gender & Subject & $\begin{array}{l}\text { Teaching } \\
\text { Qualification }\end{array}$ & $\begin{array}{l}\text { Length of } \\
\text { time } \\
\text { teaching } \\
\text { (years) }\end{array}$ & $\begin{array}{l}\text { Works at } \\
\text { Coastal College: } \\
: \text { F/T - full time, } \\
\text { P/T - part time }\end{array}$ \\
\hline Darren & Male & Plumbing & Cert. Ed. & 6 & F/T \\
\hline Chrissie & Female & Beauty & PGCE & 1 & P/T \\
\hline Jan & Female & Accountancy & PGCE & 1 & P/T \\
\hline Jo & Female & Graphic Design & Cert. Ed. & 3 & F/T \\
\hline Natasha & Female & Computing & PGCE & 4 & P/T \\
\hline Elsa & Female & Travel and Tourism & PGCE & 1 & P/T \\
\hline Toby & Male & Maths & PGCE & 1 & P/T \\
\hline
\end{tabular}

Table 2: Details of teacher students who participated in observations and interviews

\begin{tabular}{|l|l|l|l|l|}
\hline Mentor & Gender & Subject & $\begin{array}{l}\text { Length of time } \\
\text { mentoring } \\
\text { (years) }\end{array}$ & $\begin{array}{l}\text { Works at } \\
\text { Coastal } \\
\text { College: F/T - } \\
\text { full time; P/T } \\
\text { - part time }\end{array}$ \\
\hline Nigel & Male & Plumbing & 2 & F/T \\
\hline Sally & Female & Beauty & 1 & F/T \\
\hline lan & Male & Business Studies & 2 & P/T \\
\hline Liam & Male & Digital Photography & 3 & P/T \\
\hline Elaine & Female & Computing & 4 & P/T \\
\hline Maureen & Female & Travel and Tourism & 3 & F/T \\
\hline Phoebe & Female & Maths & 2 & P/T \\
\hline
\end{tabular}

Table 3: Details of mentors who participated in observations and interviews

\section{Findings}

Four key findings emerged from our analyses. Firstly, according to their own accounts, there are significant differences between how the mentors and mentees who participated in our study perceived and experienced the same mentoring interactions and relationship: notably, most mentors described their mentoring approach as developmental, whereas most teacher students paired with those mentors described it as judgemental. Secondly, our triangulated evidence, which draws on observations of mentoring conversations as well as mentors' and mentees' accounts, suggests that there was considerable variation in mentors' approaches to mentoring, with some adopting judgemental and directive methods, and others employed more developmental and nondirective methods. Thirdly, teacher students expressed mixed views on the merits and 
Author Accepted Manuscript, 28.03.2017: Manning, C. \& Hobson, A.J., Judgemental and developmental mentoring in Further Education Initial Teacher Education in England: Mentor and mentee perspectives, Research in Post-compulsory Education.

demerits of judgemental and developmental mentoring. Finally, it is clear that different mentors have completed differing amounts and types of mentor training and education, and our analyses suggest that where mentors have undertaken meaningful mentor education, they are more likely to practice developmental mentoring and less likely to enact judgemental mentoring. We elaborate upon each of these findings in what follows.

\section{Mentors' perceptions of mentoring and their mentoring approach}

When asked what they considered to be the purpose of mentoring, mentors mostly described it in terms of providing 'support' to mentees, acting as a 'guide', 'listening' and 'offering reassurance'. None of them mentioned evaluating, assessing or judging teacher students' performance. In addition, four of the mentors also explicitly describe the importance of offering 'off-line' support outside the confines of a hierarchical relationship. For example Maureen states:

[The purpose of mentoring] is to offer support and allow a forum in which people can talk about how things are going safely, which is different to what they might have with a line manager, where they might not want to confess that they're finding things difficult.

When mentors were asked about how the requirement to formally assess teacher students may impact upon their mentoring relationship there were mixed views. Three out of seven mentors considered their assessments as providing 'useful information to the university', and that sharing their 'opinion' of teacher students' progress was ' $a$ positive'. However, four mentors raised concerns about their involvement in assessment, with one describing it as a 'slightly adversarial arrangement', which made him feel at times like he was 'a boss, a minor boss'.

When asked which of the two descriptions of mentoring, as detailed in the Methods section above, best captured their approach, six out of seven mentors identified themselves as adopting a developmental model, with just one mentor, Nigel, stating that his approach was predominantly judgemental (see Table 4).

\section{Teacher students' perceptions of mentoring experiences}

Findings suggest that on the whole teacher students perceive mentors to direct mentoring meetings. Darren, Chrissie, Natasha and Elsa described their mentors as 'taking the lead' although they have opportunities to 'chip in', 'ask questions' and 'give [their] opinions' as well. Jan described her mentoring meetings as 'a bit one sided' because she 'spends a lot of time listening'. In addition, in the questionnaire the most common response from teacher students on the purpose of mentoring was to provide 'feedback' on their 'strengths and weaknesses' in order 'to improve' their teaching practice ( 8 out of 22 teacher students), which suggests a more judgemental than developmental interpretation of the process.

When mentees were asked in their interview which of the two mentoring approaches best captured their experiences of mentoring to date, their responses stood in contrast to those of their mentors. The majority of teacher students stated that the description of judgemental mentoring best captured their experience of mentoring, with 
Author Accepted Manuscript, 28.03.2017: Manning, C. \& Hobson, A.J., Judgemental and developmental mentoring in Further Education Initial Teacher Education in England: Mentor and mentee perspectives, Research in Post-compulsory Education.

just one teacher student, Toby, stating he was experiencing a more developmental approach (see Table 4).

\begin{tabular}{|l|l|l|}
\hline Mentor and teacher student & Mentor's perception & Teacher student's perception \\
\hline Nigel and Darren & Judgemental & Judgemental \\
\hline Sally and Chrissie & Developmental & Judgemental \\
\hline Ian and Jan & Developmental & Judgemental \\
\hline Liam and Jo & Developmental & Judgemental \\
\hline Elaine and Natasha & Developmental & Judgemental \\
\hline Maureen and Elsa & Developmental & Judgemental \\
\hline Phoebe and Toby & Developmental & Developmental \\
\hline
\end{tabular}

Table 4: A comparison of mentors' and teacher students' perceptions of mentoring approach/experience

Mentees considered assessment by mentors as 'part of the course' and 'to be expected'. Only Elsa acknowledged that it could potentially be problematic, but stated that it hadn't been a difficulty in her particular mentoring relationship. Jo was emphatic about the importance of assessment from her mentor, as she had found the formative reports 'motivating' and felt that if it hadn't been for the report then details around her progress would have been 'lost in unofficialdom'.

A follow up email survey sent at the end of the teaching qualification gained responses from 4 mentors and 4 mentees. Participants reported that the mentoring approach they were adopting or experiencing at the time of interview (half-way through the qualification) remained the same throughout the rest of the course.

\section{Observations of mentoring conversations}

Findings from observations of mentoring meetings reveal variation in the mentoring approaches with four mentors demonstrating a predominantly judgemental approach and three mentors using mainly developmental techniques (see Table 5). We illustrate this below by providing an overview of the most common 'mentoring moves' (FeimanNemser, 2001) observed in the judgemental and developmental mentoring meetings, respectively.

\begin{tabular}{|l|l|l|l|}
\hline $\begin{array}{l}\text { Mentor and } \\
\text { teacher student }\end{array}$ & $\begin{array}{l}\text { Mentor's } \\
\text { perception }\end{array}$ & $\begin{array}{l}\text { Teacher student's } \\
\text { perception }\end{array}$ & Observation analysis \\
\hline Nigel and Darren & Judgemental & Judgemental & Judgemental \\
\hline Sally and Chrissie & Developmental & Judgemental & Judgemental \\
\hline Ian and Jan & Developmental & Judgemental & Judgemental \\
\hline Liam and Jo & Developmental & Judgemental & Judgemental \\
\hline Elaine and Natasha & Developmental & Judgemental & Developmental \\
\hline Maureen and Elsa & Developmental & Judgemental & Developmental \\
\hline Phoebe and Toby & Developmental & Developmental & Developmental \\
\hline
\end{tabular}

Table 5 - Observations of mentoring conversations in comparison with mentors' and teacher students' perceptions of mentoring approaches/experiences 
Author Accepted Manuscript, 28.03.2017: Manning, C. \& Hobson, A.J., Judgemental and developmental mentoring in Further Education Initial Teacher Education in England: Mentor and mentee perspectives, Research in Post-compulsory Education.

\section{Judgemental approaches to mentoring meetings}

Mentors set the agenda: All mentoring meetings were opened by the mentors, with some indicating from the start they will adopt a judgemental approach: 'what we'll do is go through my observations from what I've seen today, some recommendations, but also some praise'. There are no examples of teacher students initiating the meeting or setting the agenda (Clutterbuck, 2004). Whilst mentors opening the conversation does not necessarily mean the mentoring is judgemental, it is indicative of a directive approach, with mentors leading and taking responsibility for the direction of the meeting.

Meetings centre around mentors' evaluations: There was variation in the extent to which meetings centred around mentors' evaluations. Nigel and Sally (mentors) read out their completed lesson observation feedback forms and offered a high number of evaluative statements. In both these conversations teacher students spent most of the time listening and only spoke at greater length towards the end of the meeting, when they were invited to share their ideas or questions. In the extract that follows, Darren (mentee), having listened to Nigel's feedback, then attempts to reflect on his lesson towards the end of the meeting:

Nigel: Have you got any questions or is there anything you'd like to add to development?

Darren: No, but just from my own self-criticism of today's lesson, I think maybe I should have had a list for myself of the facts on the piping diagram because I think I did miss maybe filling in a few more gaps. They did cover quite a lot, but I think maybe...

Nigel: I think you're being overcritical, because I think they knew enough.

Darren: Yeah, yeah.

Nigel: I think between them they got the key points.

Darren: Yeah, yeah, maybe yeah, but no I'm generally quite happy with it.

This exchange illustrates how Darren's reflection on his lesson is cut short when Nigel interrupts with his feedback, although the mentor may do so to emphasise his support for the teacher student and for his confidence and well-being.

Mentors give strong advice: Some mentors offered strong advice without firstly encouraging teacher students to explore available options for themselves. The following is a typical example from a mentor:

[in the lesson] you were saying "we have to wait for more people to arrive". I would say don't ever do that because, I know it's difficult to actually start the lesson without everybody else, but have something there for him [the learner] to do.

In addition, some mentors sometimes spoke in detail during mentoring meeting about their past and present experiences of teaching whilst mentees listened. This 
Author Accepted Manuscript, 28.03.2017: Manning, C. \& Hobson, A.J., Judgemental and developmental mentoring in Further Education Initial Teacher Education in England: Mentor and mentee perspectives, Research in Post-compulsory Education.

'storytelling' approach tends to be characteristic of a more directive approach to mentoring, and whilst not inevitably problematic, in this case study, some mentors' descriptions of their experiences appeared to be of marginal relevance to the conversation, and the teacher student did not always have an opportunity to draw on their own experiences in response, which could potentially be restrictive and disempowering.

\section{Developmental approaches to mentoring}

Asking open and probing questions: All mentors asked at least one open or probing question during the mentoring conversations. However Maureen, Elaine and Phoebe, who adopted a predominantly developmental approach, ask a higher number and variety of questions. Some examples, with excerpts of teacher students' responses, are offered below:
Maureen: How was it [the lesson] different to what you imagined?
Elsa: I thought the learners would be more excited by the things I was going to do with them. I thought the quiz was going to get a bit more engagement ... and that threw me a little bit I think.
Elaine: OK, so, what were the elements you brought forward from the other lesson that you talked about?
Natasha: Planning and [it's] better to have several tasks that were shorter ...And it's funny because I spoke to one of the learners at the end of the lesson .... we got talking about how he prefers to have shorter tasks...

The use of open questions prompted reflective responses from teacher students about what they perceived to go well and not so well in their observed lessons. However, even in the more developmental mentoring meetings, there were few examples of teacher students discussing how these experiences might impact on their future practice or setting their own goals for development.

Paraphrasing: Phoebe (mentor) adopted the most developmental techniques out of all the mentors and used the technique of paraphrasing in the first section of her meeting with Toby. She began by encouraging Toby to speak about his lesson uninterrupted for a few minutes, before she paraphrased back to him what she heard. Here is a short extract from Toby's summary and Phoebe's response:

Toby: Well first of all I don't know how realistic a picture you would have got as there was only half the class there. So I found it was a lot easier than it usually is, just to deal with them, as a couple of the more challenging ones weren't there ... so that means that the behaviour of the ones that were there was a lot better ...

Phoebe: So what I heard from you there was that maybe there was a slightly unrealistic impression of the group because half of them were away and a couple of the more challenging characters weren't there, so in some ways it was a slightly easier session to manage..... 
Author Accepted Manuscript, 28.03.2017: Manning, C. \& Hobson, A.J., Judgemental and developmental mentoring in Further Education Initial Teacher Education in England: Mentor and mentee perspectives, Research in Post-compulsory Education.

During this first exchange Toby spoke at some length about his lesson and made a number of analyses of students' engagement, the tasks he designed and how he felt about the lesson. Phoebe's subsequent summary offered no evaluation or comment on Toby's teaching, but rather enabled him to hear his own reflections stated back to him, and to critically reflect further on his practice.

Modelling inquiring about teaching: One technique identified by Feiman-Nemser (2001) involves mentors modelling their 'wondering' about their own teaching and encouraging the teacher student to do the same. Only Phoebe employed this mentoring move. Here is an example from her meeting with Toby:

you've got those two incredibly assertive and talkative girls. And then you had a couple who were very withdrawn in terms of their manner and their body language. And I have the same in my groups ... a couple [of students] particularly, incredibly vocal, and then some that are very quiet. How do we ensure that participation? It's a real challenge - don't you think?

Phoebe facilitated an ensuing discussion on maximising participation and seating arrangements in the classroom in which Toby reflects on the ways he has tried to combine different pairs of learners in the past.

\section{Teacher students' evaluations of judgemental and developmental mentoring approaches}

Teacher students' views of the relative pros and cons of these mentoring approaches were varied. Three of the seven teacher students who were observed and interviewed for this study stated they preferred the judgemental approach that they perceived themselves to be experiencing. Chrissie and Jo, for example, both described this approach to mentoring, which contrasted with the developmental approach they were 'expected' to take on their ITE programmes, as 'really helpful'. As Jo put is: to

sometimes it's quite nice when someone else says, "Yes this is what you did well, this is what you didn't do so well, and why don't you try, this, this and this?" ...It is easier, but sometimes you need something that's easier.

On the other hand, Darren, Jan and Natasha, who perceived their mentoring experiences as judgemental, considered such an approach to have a 'limiting' effect. Darren states:

When someone's reading [feedback] off a page it's not that personal ... you don't get as much from it. If they started by saying how did you feel you got on and asking me some questions so I'm involved in the processes as well ... you might have come to the same conclusions.

Jan, like Darren, expressed a preference for a developmental approach as it gets her to 'think more about how things are working and analyse' her teaching. If this approach were used she predicted she would 'take more away from the experience - I would learn 
Author Accepted Manuscript, 28.03.2017: Manning, C. \& Hobson, A.J., Judgemental and developmental mentoring in Further Education Initial Teacher Education in England: Mentor and mentee perspectives, Research in Post-compulsory Education.

more, I'd retain more, probably'.

\section{The role of mentor education}

During interviews mentors were asked whether they had attended any meetings for mentors or courses on mentoring. Two mentors had not received any training, and an additional two have only attended one or two meetings. However, three mentors had all opted to undertake (and successfully completed) a module on mentoring as part a postgraduate Masters (MA) course in Education. As Table 6 below shows it appears that those mentors we observed to be adopting a developmental approach have undertaken a course in mentoring, and those we found to be predominantly judgemental have had minimal training.

\begin{tabular}{|l|l|l|l|}
\hline Mentor & $\begin{array}{l}\text { Observation } \\
\text { analysis }\end{array}$ & $\begin{array}{l}\text { Attended annual mentoring } \\
\text { meeting }\end{array}$ & $\begin{array}{l}\text { Undertaken } \\
\text { postgraduate } \\
\text { mentoring module }\end{array}$ \\
\hline Nigel & Judgemental & No & No \\
\hline Sally & Judgemental & No & No \\
\hline Ian & Judgemental & Yes & No \\
\hline Liam & Judgemental & Yes & No \\
\hline Elaine & Developmental & Yes & Yes \\
\hline Maureen & Developmental & Yes & Yes \\
\hline Phoebe & Developmental & No & Yes \\
\hline
\end{tabular}

Table 6: Mentors' education or training

One mentor describes the mentoring meeting she attended as follows: 'I went on the training, well it wasn't a training session ... they told us what paperwork to fill out and how many hours we could get paid for'. Some of the mentors who had not undertaken any training struggled at times to articulate the skills associated with mentoring, with one stating, 'I don't think there's a skill you can teach, it's more about who you are'. In contrast, those mentors who have undertaken the postgraduate mentoring module described techniques such as 'active listening', 'strength based questioning', 'consciously not interrupting', and 'paraphrasing'. In addition, they demonstrated an awareness of theories and concepts related to mentoring and the wider education context by referring to: 'the mentoring continuum' (from Clutterbuck, 2004), 'being non-directive' and 'non-judgemental', 'creating a safe space', 'power relations [between mentor and mentee] and a culture of 'performativity' at the college.

\section{Conclusions and Implications}

This study extends the evidence bases on mentoring in Further Education Initial Teacher Education, and on judgemental and developmental mentoring in a number of ways. Before highlighting and discussing these, we first acknowledge a number of limitations of the research. Firstly, this study draws on a relatively small sample from a single institution. Secondly, the sample may be biased in favour of those who are in 
Author Accepted Manuscript, 28.03.2017: Manning, C. \& Hobson, A.J., Judgemental and developmental mentoring in Further Education Initial Teacher Education in England: Mentor and mentee perspectives, Research in Post-compulsory Education.

stable mentoring relationships. The initial questionnaire responses indicated that 3 out of 22 teacher students were finding their mentoring relationships problematic due to intermittent contact; however, these respondents were not included in the observations and interviews. Thirdly, we were only able to observe one meeting per mentoring pair and we only observed one type of mentoring meeting: post-lesson observation. Nonetheless, it is also important to note that mentors in this case study are only paid for the time it takes to complete the formative assessments of teacher students each year (6 hours) and some do not meet their teacher student at any other points, so for these pairs, it is likely that the meeting we observed was a fairly typical mentoring interaction.

Notwithstanding these and other limitations of the research, our study extends the evidence base, firstly, by highlighting a contradiction in the perceptions of teacher students and their mentors in reference to judgemental and developmental mentoring approaches. It may be that, as suggested by previous research, some mentors favour a developmental approach, and hence are reluctant to acknowledge (either to a researcher or themselves) they are engaging in a more judgemental version of mentoring (Cullimore and Simmons, 2010, Ingleby and Tummons, 2012, 177, Tedder and Lawy, 2009 Garbett, et al. 2013). It is also possible that some mentors may indeed consider their mentoring to be developmental, but a lack of mentor education means they have not acquired the knowledge and skills required to provide this multifaceted, menteecentred approach in practice (Klasen and Clutterbuck, 2002). This case study illustrates that even if mentors report their approach as developmental, mentees may perceive the same mentoring interaction as being judgemental - in which case the constraints upon teacher students' learning and development which arise from the over-use of judgemental mentoring, which we discussed earlier, may still arise.

Secondly, as highlighted in the Policy and Research Context above, previous studies on FE ITE have found mentors are typically adopting the role of judge or assessor. Drawing on our triangulated evidence of mentors and mentees' accounts and our own observations, our study identifies variation in terms of whether the practice is predominantly judgemental or developmental. There could be a number of reasons for this. In previous studies the emergence of judgemental mentoring has been associated with mentors' involvement in the evaluation of mentees' teaching performance (Duckworth and Maxwell, 2015; Ingleby, 2014; Tedder and Lawy, 2009). We noted earlier that the mentors in our study were required to complete four formative assessments of their mentees per year, while they had no formal role in mentees' summative assessment. This ambivalent role in relation to the evaluation and assessment of mentees, together with the fact that some mentors had undertaken meaningful mentor education and training and some had not, may largely account for the variation between judgemental and developmental approaches to mentoring employed. Our findings certainly support those of Lejonberg et al. (2015) in suggesting that mentor education has the potential to restrict the enactment of judgemental mentoring by offering mentors the understanding, awareness and skills to adopt a more multifaceted, developmental approach.

Thirdly, this case study illustrates that mentees may hold different views on the pros and cons of judgemental and developmental mentoring approaches. One view recognised in previous research (e.g. Bullough, 2005; Young et al., 2005) and the present case study is that some mentees identify that a relatively directive approach in terms of receiving constructive feedback from their mentors is beneficial. Another view raised in research on judgemental mentoring is that such an approach can restrict 
Author Accepted Manuscript, 28.03.2017: Manning, C. \& Hobson, A.J., Judgemental and developmental mentoring in Further Education Initial Teacher Education in England: Mentor and mentee perspectives, Research in Post-compulsory Education.

mentees' progress (Hobson and Malderez, 2013) and that, as some of the participants in this case study point out, a developmental approach enables mentees to be more active, resulting in the learning taking place becoming potentially more memorable. Our findings thus support the case for ONSIDE Mentoring (Hobson 2016, 2017), which recognizes the short term benefits of relatively directive mentoring for early career teachers' professional learning, development and well-being but, in the interests of their longer term development and well-being, advocates 'progressively non-directive mentoring' to support mentees to become more autonomous and agentic and to promote their learnacy (Hobson, 2016, p.101). In short, whilst mentoring is often dichotomised as developmental or judgemental, in practice mentors might take advantage of the benefits of each approach, suitably adapted to the individual development needs and dispositions of particular mentees.

Turning to consider other implications of our work for policy and practice, we would recommend that in its inspection guidance, Ofsted remove the requirement for mentors to assess teacher students and instead advocate a developmental mentoring approach whereby mentors encourage mentees to manage their on-going learning and realise their professional autonomy. In addition, we recommend there be an explicit requirement that ITE providers establish systematic and statutory mentor education, in order to equip mentors with appropriate knowledge, awareness and skills to enable them to enact developmental forms of mentoring.

Finally, we suggest that our understanding of FE ITE mentoring would benefit from further research. For example, researching a wider range of mentoring interactions, in a larger number of settings, would further help to establish the extent of judgemental and developmental mentoring approaches in the sector. In addition, a more detailed understanding of why mentors adopt a particular approach and what factors influence their enactment of mentoring may enable a better understanding of how to prepare mentors for the role. Further research into the nature and impact of mentor training and education on mentoring approaches would also facilitate the development of appropriate and effective mentor preparation programmes. Finally, investigations of how different mentoring approaches impact on teacher students' future learning and development via longitudinal studies would provide additional valuable evidence on how mentors might best support mentees in the process of learning to teach.

\section{Endnotes}

i Ofsted (The Office for Standards in Education, Children's Services and Skills) is the nonministerial department of the UK government which inspects and regulates the providers of education and skills for learners of all ages in England.

${ }^{i i}$ While the FE sector is now deregulated and legislation regarding teaching qualifications has been revoked (BIS, 2012), Ofsted continues to inspect ITE providers and guidance in the Ofsted Inspection Handbook states that mentors should conduct lesson observations and give feedback to teacher students, although in contrast to earlier Ofsted documents, does not state whether mentors are expected to grade lessons they observe.

iii The Postgraduate Certificate in Education (PGCE) is designed for university graduates and the Certificate in Education (Cert. Ed.) is for teachers who do not hold a degree. 
Author Accepted Manuscript, 28.03.2017: Manning, C. \& Hobson, A.J., Judgemental and developmental mentoring in Further Education Initial Teacher Education in England: Mentor and mentee perspectives, Research in Post-compulsory Education.

\section{References}

Aspfors, Jessica, and Göran Fransson. 2015. "Research on Mentor Education for Mentors of Newly Qualified Teachers: A Qualitative Meta-Synthesis.” Teaching and Teacher Education 48 (2015): 75-86. doi:10.1016/j.tate.2015.02.004.

Ball, Stephen J. 2003. “The Teacher's Soul and the Terrors of Performativity.” Journal of Education Policy 18 (2): 215-28. doi:10.1080/0268093022000043065.

Basit, Tehmina N. 2010. Conducting Research in Educational Contexts. New York: Continuum International Publishing Group.

Bradbury, Leslie Upson, and Thomas R. Koballa. 2008. "Borders to Cross: Identifying Sources of Tension in Mentor-intern Relationships." Teaching and Teacher Education 24 (8): 2132-45. doi:10.1016/j.tate.2008.03.002.

British Educational Research Association. 2011. "Ethical Guidelines for Educational Research.” https://www.bera.ac.uk/wp-content/uploads/2014/02/BERA-EthicalGuidelines-2011.pdf.

Bullough, Robert V. 2005. "Being and Becoming a Mentor: School-Based Teacher Educators and Teacher Educator Identity." Teaching and Teacher Education 21 (2): 143-55. doi:10.1016/j.tate.2004.12.002.

Business, Innnovation and Skills. 2012. Consultation on Revocation on Further Education Workforce Regulations: Government Response.

https://www.gov.uk/government/uploads/system/uploads/attachment_data/file/8 5883/12-970 revocation-further-education-workforce-consultation-response.pdf Bryman, Alan. 2008. “The end of the paradigm wars?”. In Handbook of Social Research, edited by P. Alasuutari, J. Brannen and L. Bickman, 13-25. London: SAGE

Bryman, Alan. 2012. Social Research Methods, 4th ed. Oxford: Oxford University Press Claxton, Guy. 2004. "Learning Is Learnable (and We Ought to Teach It)." In Ten Years On, edited by J. Cassell, 237-50. Bristol: The National Commission for Education Report.

Clutterbuck, David. 2004. Everyone Needs a Mentor: Fostering Talent in Your Organisation. 4th ed. London: Chartered Institute of Personnel and Development. 
Author Accepted Manuscript, 28.03.2017: Manning, C. \& Hobson, A.J., Judgemental and developmental mentoring in Further Education Initial Teacher Education in England: Mentor and mentee perspectives, Research in Post-compulsory Education.

Creswell, John W. 2008. Research Design: Qualitative, Quantitative, and Mixed Methods Approaches. 3rd ed. Thousand Oaks, CA: Sage Publications.

Cullimore, Sue, and Jonathan Simmons. 2010. "The Emerging Dilemmas and Challenges for Mentors and Mentees in the New Context for Training In-service Teachers for the Learning and Skills Sector.” Research in Post-Compulsory Education 15 (2): 223-39. doi:10.1080/13596741003790799.

Cunningham, Bryan. 2007. “All the Right Features: Towards an 'architecture' for Mentoring Trainee Teachers in UK Further Education Colleges." Journal of Education for Teaching 33 (1): 83-97. doi:10.1080/02607470601098351.

Duckworth, Vicky, and Bronwen Maxwell. 2015. "Extending the Mentor Role in Initial Teacher Education: Embracing Social Justice.” International Journal of Mentoring and Coaching in Education 4 (1): 4-20. doi:10.1108/ijmce-08-20140032.

Feiman-Nemser, Sharon. 2001. "Helping Novices Learn to Teach: Lessons from an Exemplary Support Teacher.” Journal of Teacher Education 52 (1): 17-30. doi:10.1177/0022487101052001003.

Foster, Rob. 1999. "School-based Initial Teacher Training in England and France:

Trainee Teachers' Perspectives Compared." Mentoring \& Tutoring: Partnership in Learning 7 (2): 131-43. doi:10.1080/1361126990070204.

Garbett, Georgina, Deborah Orrock, and Rob Smith. 2013. "Culture Clash: Mentoring Student Literacy Educators in a Marketised and Instrumentalist Further Education Policyscape.” Research in Post-Compulsory Education 18 (3): 23956. doi:10.1080/13596748.2013.819258.

Hammersley, Martyn. 1996. "The Relationship Between Qualitative And Quantitative Research: Paradigm Loyalty Versus Methodological Eclecticism.” In Handbook of Qualitative Research Methods for Psychology and the Social Sciences, edited by J. Richardson, 159-174. Leicester: British Psychological Society Books.

Hankey, Jenny. 2004. "The Good, the Bad and Other Considerations: Reflections on Mentoring Trainee Teachers in Post-Compulsory Education.” Research in PostCompulsory Education 9 (3): 389-400. doi:10.1080/13596740400200185. 
Author Accepted Manuscript, 28.03.2017: Manning, C. \& Hobson, A.J., Judgemental and developmental mentoring in Further Education Initial Teacher Education in England: Mentor and mentee perspectives, Research in Post-compulsory Education.

Hobson, Andrew J. 2016. "Judgementoring and How to Avert It: Introducing ONSIDE Mentoring for Beginning Teachers." International Journal of Mentoring and Coaching in Education 5 (2): 87-110. doi:10.1108/ijmce-03-2016-0024.

Hobson, A.J. (2017) The Terrors of Judgementoring and the Case for ONSIDE Mentoring for Early Career Teachers. In David A. Clutterbuck, Frances K. Kochan, Laura Lunsford, Nora Dominguez and Julie Haddock-Millar (Eds.), The SAGE Handbook of Mentoring, pp. 335-357. Los Angeles: SAGE Publications.

Hobson, Andrew J., and Angi Malderez. 2013. "Judgementoring and Other Threats to Realizing the Potential of School-based Mentoring in Teacher Education." International Journal of Mentoring and Coaching in Education 2 (2): 89-108. doi:10.1108/ijmce-03-2013-0019.

Hobson, Andrew J., and Joanna McIntyre. 2013. "Teacher Fabrication as an Impediment to Professional Learning and Development: The External Mentor Antidote." Oxford Review of Education 39 (3): 345-65. doi:10.1080/03054985.2013.808618.

Hobson, A, and A. Townsend. 2010. "Interviewing as Educational Method(s)." In Educational Research and Inquiry: Quantitative and Qualitative Approaches, edited by D. Hartas, 223-38. London: Continuum.

Ingleby, Ewan. 2014. "Developing Reflective Practice or Judging Teaching Performance? The Implications for Mentor Training." Research in PostCompulsory Education 19 (1): 18-32. doi:10.1080/13596748.2014.872917. Ingleby, Ewan, and John Hunt. 2008. "The CPD Needs of Mentors in Post-compulsory Initial Teacher Training in England.” Journal of In-Service Education 34 (1): 61-74. doi:10.1080/13674580701828237.

Ingleby, Ewan, and Jonathan Tummons. 2012. "Repositioning Professionalism:

Teachers, Mentors, Policy and Praxis." Research in Post-Compulsory Education 17 (2): 163-78. doi:10.1080/13596748.2012.673877.

Lawy, Robert, and Michael Tedder. 2011. "Mentoring and Individual Learning Plans: Issues of Practice in a Period of Transition." Research in Post-Compulsory Education 16 (3): 385-96. doi:10.1080/13596748.2011.602249. 
Author Accepted Manuscript, 28.03.2017: Manning, C. \& Hobson, A.J., Judgemental and developmental mentoring in Further Education Initial Teacher Education in England: Mentor and mentee perspectives, Research in Post-compulsory Education.

Lejonberg, Eli, Eyvind Elstad, and Knut-Andreas Christophersen. 2015. "Mentor Education: Challenging Mentors' Beliefs about Mentoring." International Journal of Mentoring and Coaching in Education 4 (2): 142-58. doi:10.1108/ijmce-10-2014-0034.

Lucas, Norman. 2013. “One Step Forward, Two Steps Back? The Professionalisation of Further Education Teachers in England." Research in Post-Compulsory Education 18 (4): 389-401. doi:10.1080/13596748.2013.847221.

Maier, Steven F., and Martin E. Seligman. 1976. "Learned Helplessness: Theory and Evidence.” Journal of Experimental Psychology: General 105 (1): 3-46. doi:10.1037//0096-3445.105.1.3.

Malderez, A. 2015. “On Mentoring in Supporting (English) Teacher Learning: Where Are We Now?" In Inspirations in Foreign Language Teaching: Studies in Language Pedagogy and Applied Linguistics in Honour of Peter Medgyes, edited by D. Hollo and K. Karolyi, 21-32. Harlow: Pearson.

Maynard, J, and T Furlong. "Learning to Teach and Models of Mentoring." In Issues in Mentoring, edited by T. Kerry and A. S. Myers, 34-55. London: Routledge.

McIntyre, Joanna, and Andrew J. Hobson. 2015. “Supporting Beginner Teacher Identity Development: External Mentors and the Third Space." Research Papers in Education, (2): 1-26 doi:10.1080/02671522.2015.1015438.

Miles, Matthew B., and Michael A Huberman, 1994. Qualitative Data Analysis: An Expanded Sourcebook. 2nd ed. Thousand Oaks, CA: Sage Publications.

Miles, Matthew B, Michael A. Huberman, and Johnny M. Saldana. 2013. Qualitative Data Analysis: A Methods Sourcebook. 3rd ed. Los Angeles, CA: Sage Publications.

Norman, Patricia J., and Sharon Feiman-Nemser. 2005. "Mind Activity in Teaching and Mentoring." Teaching and Teacher Education 21 (6): 679-97. doi:10.1016/j.tate.2005.05.006.

Ofsted. 2003. "The Initial Training of Further Education Teachers." http://www.ofsted.gov.uk/resources/initial-training-of-further-educationteachers-2003 
Author Accepted Manuscript, 28.03.2017: Manning, C. \& Hobson, A.J., Judgemental and developmental mentoring in Further Education Initial Teacher Education in England: Mentor and mentee perspectives, Research in Post-compulsory Education.

Ofsted. 2008. "The Initial Training of Further Education Teachers”. http://dera.ioe.ac.uk/8172/1/The\%20initial\%20training\%20of\%20further\%20ed ucation\%20teachers\%20PDF\%20format).pdf

Ofsted. 2009. "The Initial Training of Further Education Teachers”. http://dera.ioe.ac.uk/311/1/The\%20initial\%20training\%20of\%20further\%20educ ation\%20teachers.pdf

Ofsted. 2015. "ITE Inspection Handbook. " http://www.nasbtt.org.uk/wpcontent/uploads/ITE-inspection-handbook-April-2015.pdf

Orr, Kevin, and Robin Simmons. 2010. "Dual Identities: The In-service Teacher Trainee Experience in the English Further Education Sector." Journal of Vocational Education \& Training 62 (1): 75-88. doi:10.1080/13636820903452650.

Pring, Richard. 2015. Philosophy of Education Research. $3^{\text {rd }}$ ed. London: Bloomsbury. Robinson, C. \& Hobson, A.J. (2017) Mentor Education and Development in the Further Education sector in England. University of Brighton: Education Research Centre. https://www.brighton.ac.uk/_pdf/research/education/mentoraccreditation-report-final-march-2017.pdf

Saldaña, Johnny. 2012. The Coding Manual for Qualitative Researchers. 2nd ed. London, United Kingdom: SAGE Publications.

Simpson, Mary, and Jennifer Tuson. 1995. Using Observations in Small-Scale Research: A Beginner's Guide. Edinburgh: SCRE, The Scottish Council for Research in Education.

Stake, Robert. “Case Studies.” In Handbook of Qualitative Research, edited by N Denzin and Y Lincoln, 435-54. Sage: Thousand Oaks, CA.

Tedder, Michael, and Robert Lawy. 2009. “The Pursuit of 'excellence': Mentoring in Further Education Initial Teacher Training in England." Journal of Vocational Education \& Training 61 (4): 413-29. doi:10.1080/13636820903363634. Tashakkori, Abbas, and Teddlie, Charles. 2010. "Putting the Human Back in 'Human Reseach Methodology': The Researcher in Mixed Methods Research.” Journal of Mixed Methods Research 4 (271). doi:10.1177/1558689810382532 
Author Accepted Manuscript, 28.03.2017: Manning, C. \& Hobson, A.J., Judgemental and developmental mentoring in Further Education Initial Teacher Education in England: Mentor and mentee perspectives, Research in Post-compulsory Education.

Tee Ng, Pak. 2012. "Mentoring and Coaching Educators in the Singapore Education System." International Journal of Mentoring and Coaching in Education 1 (1): 24-35. doi:10.1108/20466851211231602.

Tomlinson, Peter. 1989. "Having It Both Ways: Hierarchical Focusing as Research Interview Method.” British Educational Research Journal 15 (2) (January): 155-76. doi:10.1080/0141192890150205.

Tummons, Jonathan . 2014. "Using Software for Qualitative Data Analysis: Research Outside Paradigmatic Boundaries" In Big Data? Qualitative Approaches to Digital Research. Published online: 06 Nov 2014.155-177. doi.org/10.1108/S1042-319220140000013010

Young, Janet R., Robert V. Bullough, Jr, Roni Jo Draper, Leigh K. Smith, and Lynnette B. Erickson. 2005. "Novice Teacher Growth and Personal Models of Mentoring: Choosing Compassion over Inquiry." Mentoring \& Tutoring: Partnership in Learning 13 (2): 169-88. doi:10.1080/13611260500105477.

Yusko, B, and S. Feiman Nemser. 2008. "Embracing Contraries: Combining Assistance and Assessment in New Teacher Induction." Teachers College Record 110 (7): $1-12$. 